\title{
Effectiveness of interventions to screen and manage infections during pregnancy on reducing stillbirths: a review
}

Sidra Ishaque ${ }^{1}$, Mohammad Yawar Yakoob', Aamer Imdad', Robert L Goldenberg², Thomas P Eisele ${ }^{3}$, Zulfiqar A Bhutta ${ }^{*}$

\begin{abstract}
Background: Infection is a well acknowledged cause of stillbirths and may account for about half of all perinatal deaths today, especially in developing countries. This review presents the impact of interventions targeting various important infections during pregnancy on stillbirth or perinatal mortality.

Methods: We undertook a systematic review including all relevant literature on interventions dealing with infections during pregnancy for assessment of effects on stillbirths or perinatal mortality. The quality of the evidence was assessed using the adapted Grading of Recommendations, Assessment, Development and Evaluation (GRADE) approach by Child Health Epidemiology Reference Group (CHERG). For the outcome of interest, namely stillbirth, we applied the rules developed by CHERG to recommend a final estimate for reduction in stillbirth for input to the Lives Saved Tool (LiST) model.

Results: A total of 25 studies were included in the review. A random-effects meta-analysis of observational studies of detection and treatment of syphilis during pregnancy showed a significant $80 \%$ reduction in stillbirths [Relative risk $(\mathrm{RR})=0.20 ; 95 \%$ confidence interval $(\mathrm{Cl})$ : 0.12 - 0.34) that is recommended for inclusion in the LiST model. Our meta-analysis showed the malaria prevention interventions i.e. intermittent preventive treatment (IPTp) and insecticide-treated mosquito nets (ITNs) can reduce stillbirths by $22 \%$, however results were not statistically significant (RR $=0.78 ; 95 \% \mathrm{Cl}: 0.59$ - 1.03). For human immunodeficiency virus infection, a pooled analysis of 6 radomized controlled trials (RCTs) failed to show a statistically significant reduction in stillbirth with the use of antiretroviral in pregnancy compared to placebo ( $R R=0.93 ; 95 \% \mathrm{Cl}: 0.45-1.92)$. Similarly, pooled analysis combining four studies for the treatment of bacterial vaginosis ( 3 for oral and 1 for vaginal antibiotic) failed to yield a significant impact on perinatal mortality $(\mathrm{OR}=0.88 ; 95 \% \mathrm{Cl}: 0.50-1.55)$.

Conclusions: The clearest evidence of impact in stillbirth reduction was found for adequate prevention and treatment of syphilis infection and possibly malaria. At present, large gaps exist in the growing list of stillbirth risk factors, especially those that are infection related. Potential causes of stillbirths including HIV and TORCH infections need to be investigated further to help establish the role of prevention/treatment and its subsequent impact on stillbirth reduction.
\end{abstract}

\section{Background}

Stillbirth, defined as a newborn having no sign of life at delivery, is one of the most common adverse outcomes of pregnancy. About 3.2 million stillbirths occur worldwide each year [1]. The highest overall figures of

\footnotetext{
*Correspondence: zulfiqar.bhutta@aku.edu

'Division of Women and Child Health, The Aga Khan University, Stadium Road, P.O. Box 3500, Karachi-74800, Pakistan

Full list of author information is available at the end of the article
}

stillbirths have been reported from countries in SouthEast Asia and sub-Saharan Africa [1]. Globally, infection is a leading cause of stillbirth and accounts for an estimated half of all stillbirths today, especially in developing countries [2]. A notable association exists between infection and gestational age. A review reported that the earlier the fetal death during gestation, the more likely it is to be caused by an infection [3]. For example, in one study, $19 \%$ of fetal deaths less than 28 weeks were

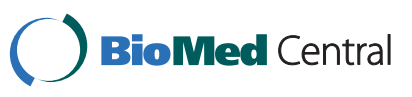

() 2011 Ishaque et al; licensee BioMed Central Ltd. This is an open access article distributed under the terms of the Creative Commons Attribution License (http://creativecommons.org/licenses/by/2.0), which permits unrestricted use, distribution, and reproduction in any medium, provided the original work is properly cited. 
associated with an infection, while only $2 \%$ of term stillbirths were infection-related [4]. Direct infection, placental damage, and severe maternal illness are the most commonly reported mechanisms by which infections may cause stillbirths [5].

Among infections, various organisms have been implicated as causing stillbirth, including bacteria, viruses, protozoa, helminthes and fungi [6]. Syphilis remains an avoidable cause of infection related stillbirths Plasmodium falciparum malaria has been associated with stillbirth especially in primigravidas owing to its high prevalence and extensive placental damage [7]. TORCH infections, which include Toxoplasmosis, Other (syphilis, varicella-zoster, parvovirus B19), Rubella, Cytomegalovirus (CMV), and Herpes infections, are infections during pregnancy that are associated with congenital anomalies and possibly stillbirths $[8,9]$. Most of the TORCH infections cause mild maternal morbidity, but have serious fetal consequences [8]. Periodontal disease is another important chronic infectious disease of humans which is commonly present in pregnancy [10]. It's prevalence range from 35 to $100 \%$ (especially gingivitis) during pregnancy [11]. The risk of adverse pregnancy outcomes including preterm birth, fetal growth restriction may be increased in women with periodontal disease [12-15]. This may be the result of systemic inflammatory responses due to a persistent periodontal infection, or periodontal disease may be a marker for infection elsewhere in the body $[12,16]$. Helminthiasis is infestation of the human body by parasitic worms [17]. Millions of pregnant women globally are infected with intestinal nematodes [18] which leads to chronic blood loss, and can be a major cause of iron deficiency anemia in reproductive age, which is a risk factor for adverse perinatal outcome [19]. A more detailed description of background literature on maternal infections during pregnancy and their association with stillbirths is given in Additional File 1.

The objective of this review was to synthesize up-to-date evidence on the role of diagnosis and management of infections in pregnancy and their effects on stillbirth. This paper is a part of series of papers reviewing the effect of interventions to be included in the Live Saved Tool (LiST) [20]. This process involves qualitative assessment of available evidence according to the Grading of Recommendations, Assessment, Development and Evaluation (GRADE) approach and quantitative analysis based on rules developed by the Child Health Epidemiology Reference Group (CHERG) [20,21]. More details about CHERG methods and LiST are available in the methods section of this paper and the CHERG methods paper [20].

\section{Methods}

\section{Literature search}

We searched all relevant literature on interventions dealing with infections during pregnancy to quantify their impact on stillbirths and perinatal mortality. The last date of the search was February $1^{\text {st }} 2010$. The following infections were included in this review: syphilis, $P$. falciparum malaria, HIV, bacterial vaginosis, ascending bacterial infections (chorioamnionitis), asymptomatic bacteriuria, periodontal disease, helminthiasis, and TORCH infections. The databases searched included PubMed, the Cochrane Library, The Lancet Series and hand search of bibliographies of relevant reviews. Experts were also contacted in the field for unpublished data. The search strategy for different infections is given in Additional File 2:

\section{Selection (inclusion/exclusion criteria)}

The study designs primarily considered were randomized and quasi-randomized trials however observational studies were also considered where data were not available from randomized trials. There was no restriction on language or publication status. There were no limits on gestational age at the time of enrolment in the study. For IPTp (intermittent preventive treatment of P. Falciparum), we sought studies that measured the effect of at least 2-doses per pregnancy of IPTp with sulfadoxine-pyrimethamine versus a placebo, independent of Insecticide treated nets (ITNs). Trials that compared 2-doses of IPTp to another drug (not a placebo) were excluded, as were trials that assessed IPTp compared to ITNs where the effect of IPTp against a placebo could not be isolated. For ITNs, we sought studies that measured the effect of access to ITNs among pregnant women versus no ITNs on stillbirths. Trials that compared ITNs to untreated nets were excluded, as were trials that assessed ITNs plus IPTp where the effect of ITNs against no mosquito net (placebo) could not be isolated.

\section{Data abstraction and validity assessment}

Each study that satisfied the eligibility criteria was included in the review. A standardized data extraction sheet was used [20]. The data were abstracted for key variables like; participants' characteristics, sample size, location, study design and limitations, description of intervention and control groups.

The individual studies were graded according to CHERG adaptation of GRADE criteria [20]. A study was graded as that of 'high' 'moderate' 'low' or 'very low' quality based on strengths and limitations of the study. Studies received an initial score of high if they were a randomized or cluster randomized trial. The grade was decreased one grade for each study design limitation. In addition, studies reporting an intent-to-treat analysis or with statistically significant strong levels of association (>80\% reduction) received $0.5-1$ grade increases. Any study with a final grade of very low was excluded. The 
overall quality of evidence of an outcome was also assessed and graded according to the CHERG adaptation of the GRADE technique [20]. This assessment was based on three components: 1) the volume and consistency of the evidence; 2) the size of the effect, or risk ratio; and 3) the strength of the statistical evidence for an association between the intervention and outcome, as reflected by the p-value $[20,21]$.

\section{Quantitative data synthesis}

We performed meta-analyses where data were available from more than one study for an outcome. The primary outcomes of interest were stillbirths and perinatal mortality. The reason for including perinatal mortality as an outcome was based on the fact most of the studies do not report disaggregated data for stillbirths but do that by combining stillbirths with early neonatal deaths (i.e. perinatal mortality). This exercise is in accordance with the basics of CHERG rules which take into account the biological plausibility of the intervention and limitations of measured outcomes [20]. For example studies may not collect the outcome of interest (e.g., pneumonia mortality) but may collect data on severity of disease (e.g. hospital admission). CHERG rules will thus consider a range of outcomes (where necessary) and choose a point estimate which is the most conservative and represent the expected effect of the intervention based on biological plausibility [20].

We used dichotomous values for pooling the data, except for insecticide-treated mosquito nets (ITNs) where data were pooled by generic inverse variance method of meta-analysis. The summary estimates were described as relative risk (RR) or Odd ratios (OR) with $95 \%$ confidence interval (CI). The assessment of statistical heterogeneity among trials pooled data was done by visual inspection (i.e. the overlap of the confidence intervals among the studies), Chi square (P-value) and $\mathrm{I}^{2}$ values. An $\mathrm{I}^{2}$ value greater than $50 \%$ was taken to represent substantial heterogeneity in the pooled data. In case of substantial heterogeneity, causes were explored by sensitivity analysis. A random effects model was used for the meta-analysis in case of substantial heterogeneity. All the analyses were conducted using Review Manager 5 [22]. We applied the CHERG Rules for Evidence Review to recommend a final estimate for reduction in stillbirth from interventions for a specific maternal infection during pregnancy [20].

\section{Results}

A total of 1155 hits were identified from our search strategies (Figure 1). After screening the titles and abstracts, 84 studies were initially considered eligible. We thoroughly reviewed the abstracts and full texts, where available and 25 studies were selected for inclusion in the meta-analyses (Additional file 3). Additional File 4 outlines the characteristics of included studies.

\section{Syphilis}

No randomized trials were found for treatment of syphilis and its effect on prevention on stillbirths. However, a random-effects meta-analysis of 8 observation studies by Blencowe et al. in this supplement has shown an estimated reduction of $80 \%$ (RR 0.20 , 95\% CI $0.12-0.34$ ) in syphilis related stillbirths with use of penicillin [23]. It is however important to note that none of the included studies in this meta-analysis made any attempt to control for systematic differences between treated and untreated women (confounding). For example women not attending antenatal clinic and/ or not complying with complex penicillin treatment regimens may differ in their risk profiles for stillbirth, preterm delivery and neonatal death from fully compliant infected women.

\section{Malaria}

There were 6 randomized controlled trials that addressed prevention of malaria during pregnancy by IPTp or ITN. As the effects of IPTp and ITNs used during pregnancy have similar causal pathways for preventing stillbirth, and as there is no evidence of a synergistic effect between them [24], the data were pooled irrespective of method used. The combined results show $22 \%$ reduction in stillbirths $(\mathrm{RR}=0.78$; 95\% $\mathrm{CI}: 0.59-1.03)$ (Figure 2). A subgroup analysis of three trials [25-27] that evaluated the impact of IPTp with sulfadoxine-pyrimethamine vs. placebo showed no effect on stillbirth $(\mathrm{RR}=0.96$; 95\% CI: $0.62-1.50$; fixed model $)$ or perinatal mortality $(\mathrm{RR}=0.78 ; 95 \% \mathrm{CI}: 0.52-1.17$; fixed model). Pooled results of three studies that used ITNs in pregnancy yielded a statistically significant association with reduced fetal loss (RR $0.67,95 \%$ CI 0.47 to 0.97 ) compared to controls.

\section{HIV}

Our pooled meta-analysis of 6 studies [28-33] failed to show a statistically significant reduction in stillbirth when the use of anti-retrovirals in pregnancy was compared to control (RR 0.93 95\% CI 0.45 - 1.92) (See Figure 3).

\section{Bacterial vaginosis}

Our pooled analysis combining four studies [34-37] showed a non-significant impact of treatment of bacterial vaginosis on perinatal mortality (OR 0.88 95\% CI $0.50-1.55)$. Sub-group analysis showed similar results with the use of oral (OR $0.9695 \%$ CI $0.53-1.73$ ) and vaginal (OR 0.35 95\% CI 0.05 - 2.52) antibiotics (Fig 4). There are no data on Still Births. 


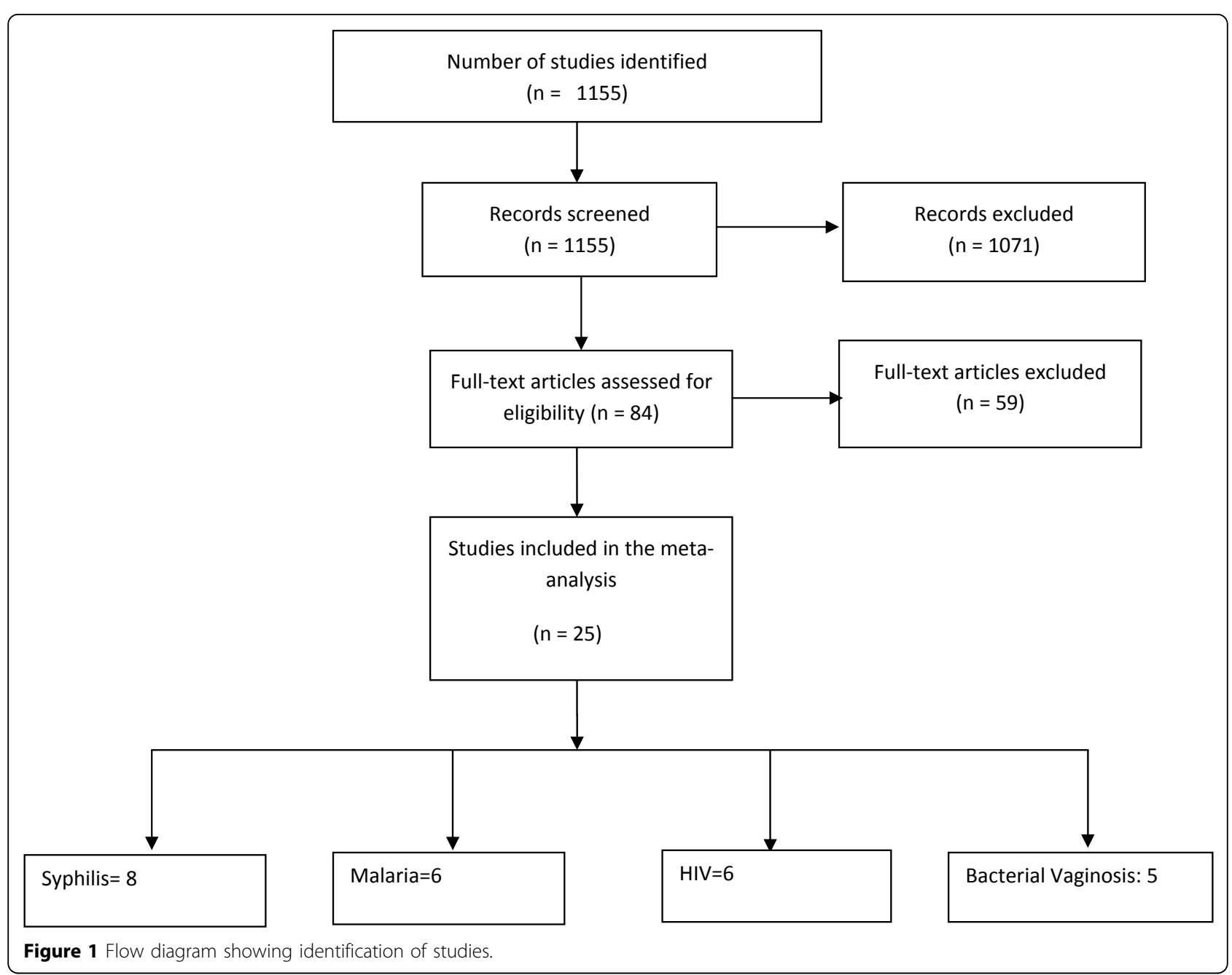

\section{Chorioamnionitis}

The Cochrane review by Kenyon et al. [38] studies the use of antibiotics for preterm premature rupture of membrane (pPROM) and reports a statistically significant 43\% reduction in risk of chorioamnionitis $(\mathrm{RR}=0.57 ; 95 \% \mathrm{CI}$ : 0.37 - 0.86). There was however no impact on perinatal mortality/or fetal death before discharge $(R R=0.90$; $95 \%$ CI: $0.74-1.10)$. Another Cochrane review by Flenady and King [39] on antibiotics for PROM at or near term showed no impact of antibiotics on chorioamnionitis (RR $=0.60 ; 95 \%$ CI: $0.30-1.18)$ nor on perinatal mortality $(\mathrm{RR}=0.98 ; 95 \% \mathrm{CI}: 0.14-6.89)$. There were no separate data on stillbirth.

\section{Asymptomatic bacteriuria}

Studies have looked at the association between asymptomatic bacteriuria during pregnancy and perinatal mortality. In a study performed from 1972 to 1979, pregnant women with asymptomatic bacteriuria had a significantly higher perinatal mortality (64.9 vs. 15.6, p <
0.001) [40]. However, a more recent population-based retrospective study by Sheiner et al. showed that patients with asymptomatic bacteriuria, in whom antibiotic treatment was recommended, had similar perinatal mortality rates compared to women without asymptomatic bacteriuria ( $1.5 \%$ vs. $1.4 \%, \mathrm{P}=0.707)$ [41]

\section{Periodontal disease}

While published data convincingly display a link between periodontal disease and stillbirth incidence $[10,15,42-44]$, there is limited literature on interventions for periodontal disease and impact on stillbirths. The systematic review by Polyzos et al. [14] studied the impact of periodontal care during pregnancy and found a non-significant effect on abortions and stillbirths (OR $=0.73 ; 95 \% \mathrm{CI}: 0.41$ to 1.31$)$. In a recent randomized controlled trial, 1082 pregnant women with periodontal disease were allocated either to receive periodontal treatment in mid-pregnancy or after delivery. There were four unexplained stillbirths in the control group 


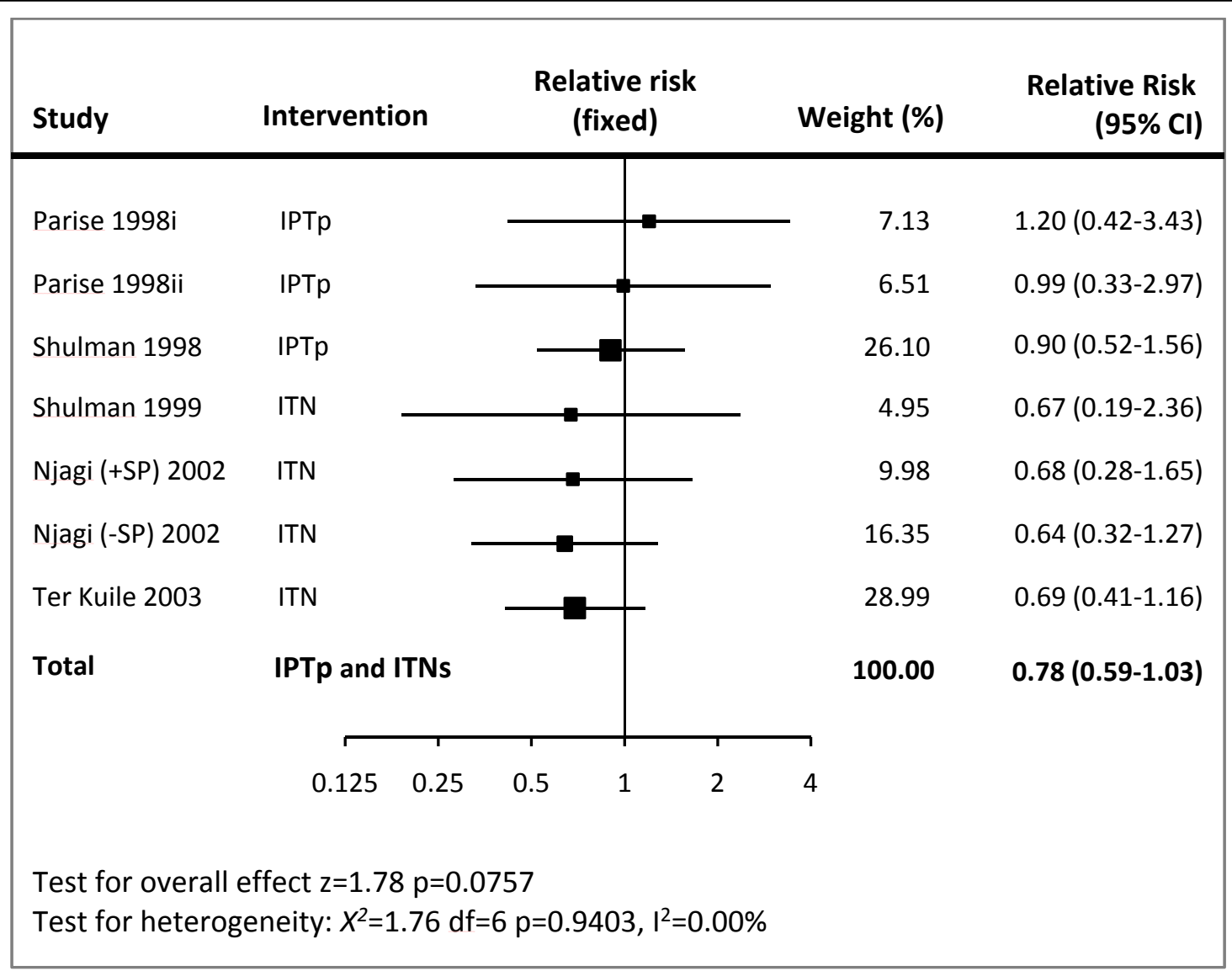

Figure 2 Forest plot for meta-analysis of the effect of malaria prevention in pregnancy (IPTp and ITNs) used during first or second pregnancy on preventing stillbirths.

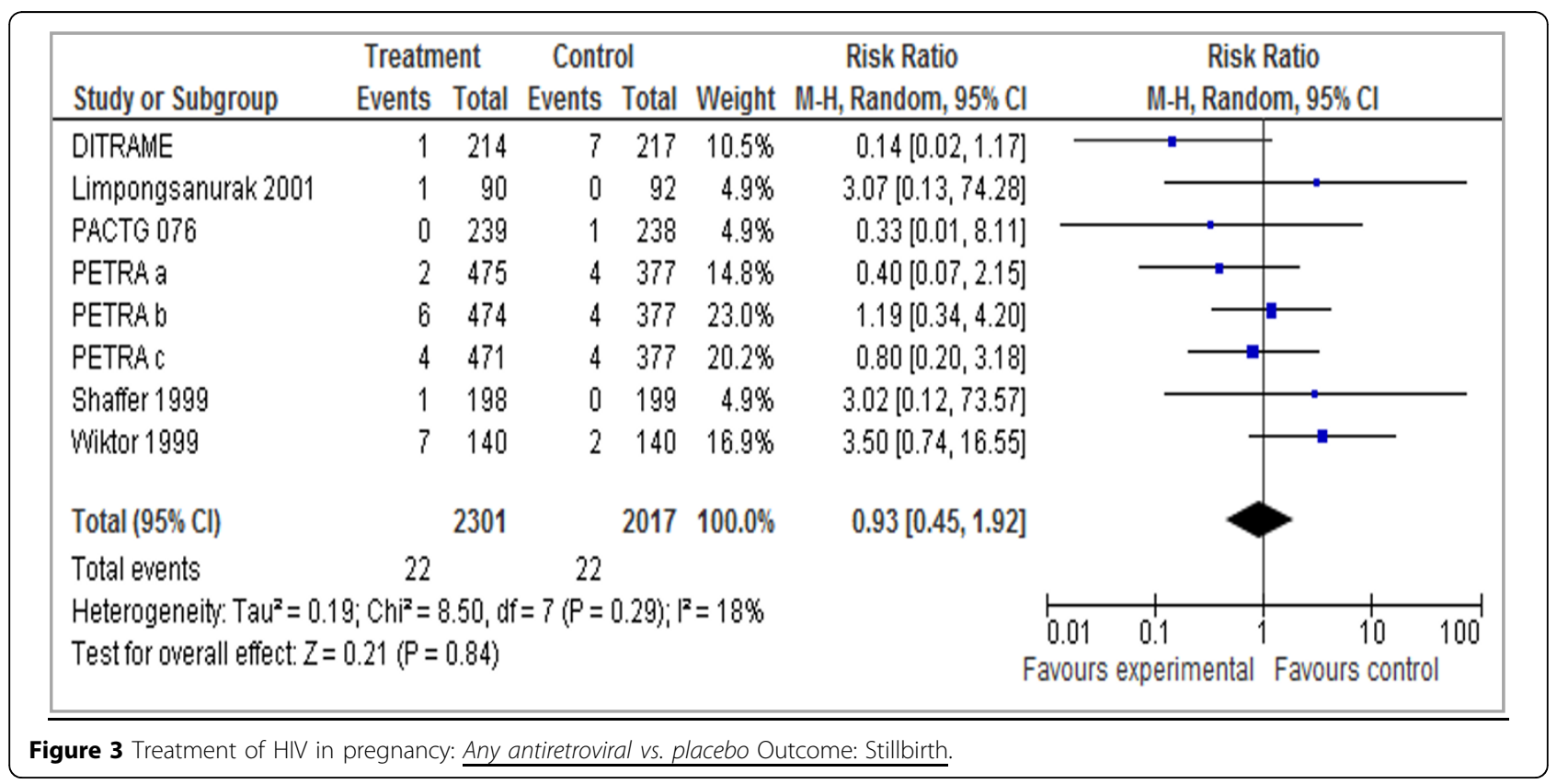




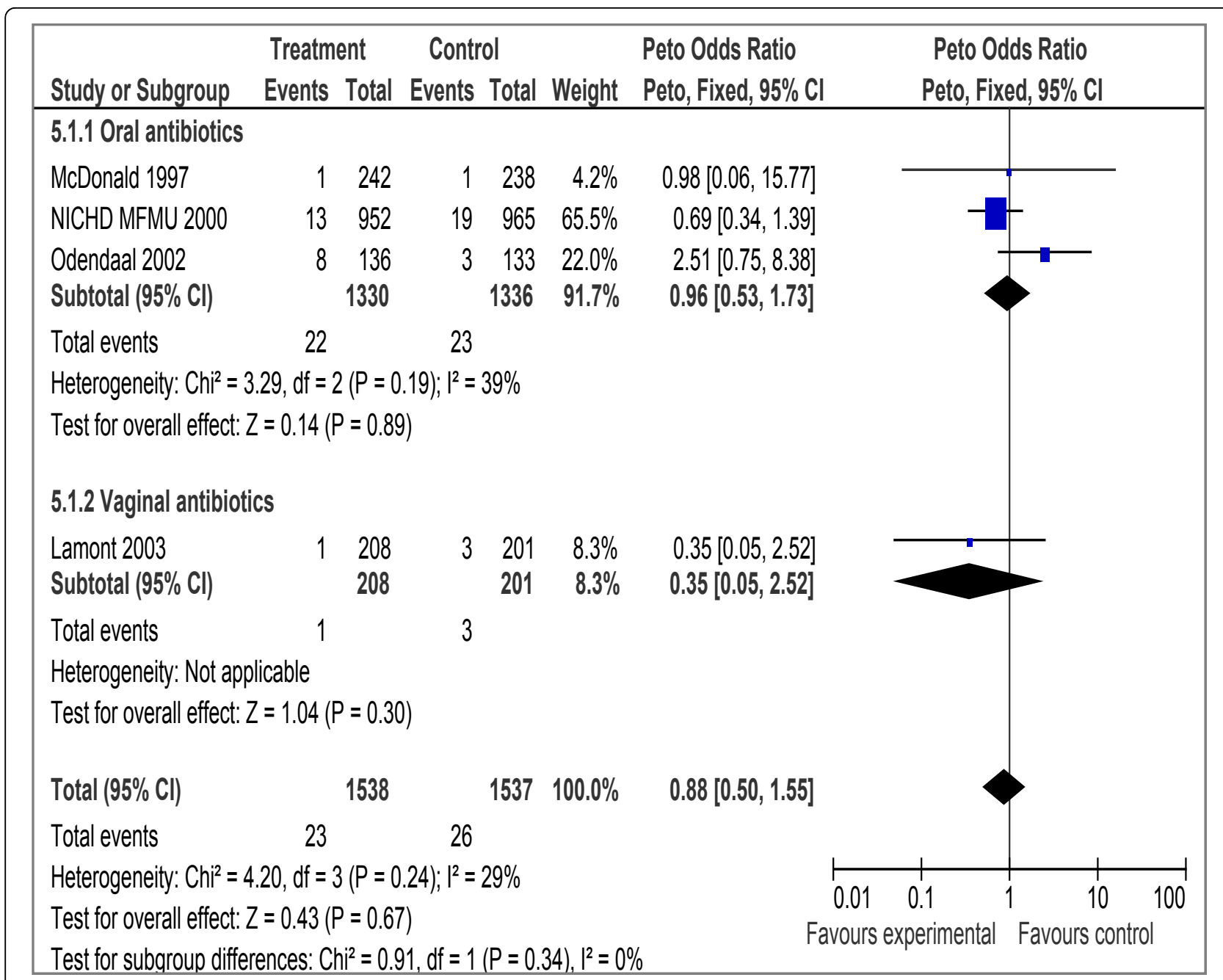

Figure 4 Treatment of bacterial vaginosis in pregnancy: Any antibiotic versus placebo/no Outcome: Perinatal death.

and no losses in the treated group, but the results were non-significant $(P=0.12)$ [45]. A meta-analysis on periodontal care during pregnancy versus treatment after birth based on two studies [13,45] has shown a 70\% significant reduction in stillbirth $(\mathrm{RR}=0.30 ; 95 \% \mathrm{CI}: 0.12$ - 0.76) (Philippa Middleton, personal communication).

\section{Helminthiasis}

A recent study from Uganda on deworming during pregnancy has shown no effect of treatment with albendazole or praziquantel on incidence of stillbirths compared to placebo [46]. Another open label, randomized controlled trial from Uganda that compared ivermectin, albendazole, combined ivermectin/albendazole compared with placebo showed similar results $(\mathrm{P}=0.13)$ [47]. The Cochrane review by Haider et al. reported the pooled effect of use of anti-helminthic therapy on perinatal mortality based on two RCTs $[48,49]$ and showed no overall effect $(R R=1.10 ; 95 \%$ CI: $0.55-2.22)$.
TORCH INFECTION: TOXOPLASMOSIS, OTHER (SYPHILIS, VARICELLA-ZOSTER, PARVOVIRUS B19), RUBELLA, CYTOMEGALOVIRUS (CMV), AND HERPES INFECTIONS

A case control study from Jordan reports that the presence of Toxoplasmosis gondii was significantly higher in those with adverse pregnancy outcomes compared to controls ( $54 \%$ vs. $12 \%, \mathrm{p}<0.02)$ [50]

Maternal rubella has been implicated as a cause of stillbirths [51]. In Guinea-Bissau, stillbirth rates were increased 4- to 9-fold if the mother was infected with rubella during her pregnancy [3].

\section{Cytomegalovirus}

A study from Australia [52] reported that $9 \%$ of blood samples taken from stillbirths by cardiac puncture were PCR positive for CMV. A recent study from Greece using PCR, showed significantly increased levels of CMV (16\%) in the placentas of stillbirths compared to controls (3\%) [53]. 
Herpes simplex infections have also been described as a cause of fetal death [54]. However, Herpes simplex viruses rarely, if ever, cause stillbirth, likely because the virus rarely causes an intrauterine infection. Neonatal infections are acquired during fetal passage through an infected birth canal. There is a paucity of evidence with regards to the significance of Herpes virus in causing stillbirths. Also, whether treatment and prevention have a significant positive impact on adverse pregnancy outcomes remains elusive.

Tables $1-4$ outline the quality grading of the overall evidence of all the interventions considered in this review and described below in the same order.

\section{Discussion}

Syphilis remains a major cause of avoidable perinatal death in many countries despite being treatable, and despite the WHO recommendation that all pregnant women be tested as part of routine antenatal care. Most studies report syphilis to have a relative risk of stillbirth in the range of 2 to 5; however, a Tanzanian study reported a relative risk of 18 for women with active syphilis [55]. In some areas of sub-Saharan Africa, about $25 \%$ to $50 \%$ of all stillbirths were associated with syphilis [56]. Syphilis also contributes to stillbirths in other areas of the world including Russia, Asia and South America [57]. The findings of a meta-analysis by Blencowe et al. correlate with the above observations and shows that treatment of syphilis during pregnancy can significantly reduce syphilis related stillbirths by up to $80 \%$ [23]. This estimate has been recommended for inclusion in the LiST model with a quality grade of 'low' (Table 1). The overall evidence was graded as 'low' as all the included studies in the meta-aalysis were observational studies.

Malaria in pregnancy is an important preventable cause of maternal and perinatal morbidity and mortality [7]. The WHO advocates a three-pronged approach to control malaria in pregnancy that includes the use of ITNs, IPTp and case management of parasitemia with artemisin-based therapies, especially in areas where malaria is endemic [58]. Our meta-analysis suggests that malaria prevention interventions in pregnancy (IPTp or ITNs) can reduce stillbirths by $22 \%$ in malaria endemic countries $(R R=0.78 ; 95 \% C I: 0.59-1.03)$. While this effect is only marginally significant (and thus graded as that of 'moderate' quality in table 4), there is other evidence to suggest that such interventions could be highly effective in improving maternal and birth outcomes [58-61]. This is supported by the fact that IPTp has been shown to significantly reduce placental malaria, as well as maternal anemia [60], which are associated with adverse pregnancy outcome.

The pandemic of human immunodeficiency virus (HIV) in pregnancy is one of the major health problems today [63]. Maternal HIV infection may increase the risk of stillbirth [64]. A study from Zambia has reported an inverse relationship between decreasing CD4 cell counts in HIV seropositive women and stillbirth $(\mathrm{P}=0.000)$ [65]. Our pooled analysis however failed to show a statistically significant reduction in stillbirth when antiretrovirals for pregnant women were compared to placebo $(R R=0.93 ; 95 \%$ CI $0.45-1.92)$ and thus no recommendations have been made for LiST regarding this intervention. Results of our review are consistent with the results from a Cochrane Review by Volmink et al [66]. Data was not pooled in this Cochrane review however none of the six included trials showed a significant impact of antiretrovirals in pregnancy on stillbirth [66]. Pooled analysis from a review by Suksomboon et al. [67], that included five randomized trials, showed a non-significant impact on stillbirth ( $R R=1.11$ 95\% CI 95\% 0.48- 2.56).

Bacterial vaginosis in pregnant women is common, ranging from $14 \%$ to $21 \%$ in Western countries and 13.6-18\% in Asian countries [68]. However, very few perinatal deaths have been reported in relation to maternal bacterial vaginosis [68]. Mc Donald reports a non-significant association of the treatment of bacterial vaginosis in pregnancy with reduction in perinatal mortality [34]. Our meta-analysis of four studies (3 for oral and 1 for vaginal antibiotic) failed to yield a significant impact on perinatal mortality (Figure 4). Whether treatment of bacterial vaginosis will reduce stillbirths is unknown and would need to be validated by future trials. Applying the CHERG Rules for Evidence Review, studies included for bacterial vaginosis and perinatal

Table 1 Quality assessment of trials of interventions for infections (syphilis) in pregnancy

\begin{tabular}{|c|c|c|c|c|c|c|c|c|}
\hline \multirow[b]{3}{*}{$\begin{array}{l}\text { No of } \\
\text { studies } \\
\text { (ref) }\end{array}$} & \multicolumn{5}{|c|}{ Quality Assessment } & \multicolumn{3}{|c|}{ Summary of Findings } \\
\hline & \multirow[b]{2}{*}{ Design } & \multirow[b]{2}{*}{ Limitations } & \multirow[b]{2}{*}{ Consistency } & \multicolumn{2}{|c|}{ Directness } & \multicolumn{2}{|c|}{ No of events } & \multirow[b]{2}{*}{$\begin{array}{c}\text { Relative } \\
\text { Risk (95\% } \\
\text { Cl) }\end{array}$} \\
\hline & & & & $\begin{array}{c}\text { Generalizability to } \\
\text { population of } \\
\text { interest }\end{array}$ & $\begin{array}{c}\text { Generalizability to } \\
\text { intervention of } \\
\text { interest }\end{array}$ & Intervention & Control & \\
\hline \multicolumn{9}{|c|}{ Syphilis and stillbirth: LOWoutcome specific quality } \\
\hline 8 & $\begin{array}{l}\text { Observational } \\
\text { studies }\end{array}$ & none & $\begin{array}{c}\text { Some heterogeneity and } \\
5 \text { out of } 8 \text { studies show } \\
\text { benefit }\end{array}$ & Yes & Yes & Not available & $\begin{array}{c}\text { Not } \\
\text { available }\end{array}$ & $\begin{array}{c}0.20(0.12 \\
-0.34)\end{array}$ \\
\hline
\end{tabular}


Table 2 Quality assessment of trials of the evidence for prevention in malaria in pregnancy (IPTp and ITNs) used during first or second pregnancy for preventing stillbirths

\begin{tabular}{|c|c|c|c|c|c|c|c|c|c|c|}
\hline \multirow[b]{3}{*}{$\begin{array}{l}\text { No of } \\
\text { studies }\end{array}$} & \multirow[b]{3}{*}{ Design } & \multirow[b]{3}{*}{ Limitations } & \multicolumn{3}{|c|}{ Quality assessment } & \multicolumn{5}{|c|}{ Summary findings } \\
\hline & & & & \multicolumn{2}{|c|}{ Directness } & \multicolumn{2}{|c|}{ Intervention } & \multicolumn{2}{|c|}{ Control } & \multirow[b]{2}{*}{$\begin{array}{r}\text { RR } \\
(95 \% \\
\mathrm{Cl})\end{array}$} \\
\hline & & & $\begin{array}{l}\text { Consistency of } \\
\text { results }\end{array}$ & $\begin{array}{l}\text { Generalizability } \\
\text { to population } \\
\text { of interest }\end{array}$ & $\begin{array}{l}\text { Generalizability } \\
\text { to intervention } \\
\text { of interest }\end{array}$ & $\begin{array}{r}\text { Number } \\
\text { of } \\
\text { events }\end{array}$ & Denominator & $\begin{array}{r}\text { Number } \\
\text { of } \\
\text { events }\end{array}$ & Denominator & \\
\hline \multicolumn{11}{|c|}{ IPTp for preventing stillbirths:High outcome-specific quality } \\
\hline 3 & $\mathrm{RCT}$ & & $\begin{array}{l}\text { Consistent } X^{2} \\
\text { for } \\
\text { heterogeneity } \\
(2 \mathrm{df})=0.23\end{array}$ & High & High & 44 & 1,489 & 36 & 1,083 & $\begin{array}{r}0.96 \\
(0.62- \\
1.50)\end{array}$ \\
\hline \multicolumn{11}{|c|}{ ITNs for preventing stillbirths:High outcome-specific quality } \\
\hline 4 & CRCT & $\begin{array}{l}\text { Not } \\
\text { blinded }\end{array}$ & $\begin{array}{l}\text { Consistent } X^{2} \\
\text { for } \\
\text { heterogeneity } \\
(3 \mathrm{df})=0.03\end{array}$ & High & High & Unknown & Unknown & Unknown & Unknown & $\begin{array}{r}0.67 \\
(0.47- \\
0.97)\end{array}$ \\
\hline \multicolumn{11}{|c|}{ Effect of IPTp and ITNs combined on stillbirths :Moderate outcome-specific quality } \\
\hline 7 & $\begin{array}{l}\mathrm{RCT} / \\
\mathrm{CRCT}\end{array}$ & & $\begin{array}{l}\text { Consistent } X^{2} \\
\text { for } \\
\text { heterogeneity } \\
(6 \mathrm{df})=1.76\end{array}$ & High & High & Unknown & Unknown & Unknown & Unknown & $\begin{array}{r}0.78 \\
(0.59- \\
1.03)\end{array}$ \\
\hline
\end{tabular}

RCT: Randomized controlled trial: CRCT: Community randomized controlled trial: RR: Relative risk: Cl: Confidence Interval.

death were ranked as having a 'moderate' grade of evidence. Included studies had limitations, including a low recruitment response and unclear allocation concealment. The evidence to date does not suggest any benefit of screening and treating all pregnant women for asymptomatic BV to prevent stillbirths. Although antibiotic treatment targeting bacterial vaginosis may be of value in some women [37], further research needs to be carried out to study the potential impact of antibiotics on chorioamnionitis, which is a well-established risk factor for stillbirth [6].

There are very few RCTs that have looked at the impact of periodontal care on stillbirth or perinatal mortality, with most trials reporting preterm birth as an outcome. A recent meta-analysis of periodontal care suggests that there may be an impact on stillbirths (Middleton P, 2010 personal communication), but needs confirmation in further trials from developing countries. This is an emerging area of research that needs more studies.
There is very limited evidence of the impact of antihelminthic therapy on stillbirths. There has been a tendency towards increased risk of stillbirths and perinatal mortality that is non-significant based on RCTs [17]. Maternal deworming, however, does hold promise for improving the health of pregnant women in endemic areas, particularly in terms of alleviating risk of anemia and subsequently the risk of adverse pregnancy outcomes [18]. It is, therefore, recommended in specific, situational contexts such as where soil associated helminthiasis rates are high and iron-deficiency anemia rates endemic [69].

TORCH infection is an important risk factor for stillbirths [8]. However, the pathways which lead from infectious risk factors to fetal death are, for the most part, not well defined [70,71]. There is a dearth of good quality evidence on association of treatment of TORCH on stillbirth and we recommend further research to study the associations of these infections with stillbirth and perinatal mortality.

Table 3 Quality assessment of trials of interventions for infections (HIV) in pregnancy

\begin{tabular}{|c|c|c|c|c|c|c|c|c|}
\hline \multicolumn{6}{|c|}{ Quality Assessment } & \multicolumn{3}{|c|}{ Summary of Findings } \\
\hline & & & & \multicolumn{2}{|c|}{ Directness } & \multicolumn{3}{|c|}{ No of events } \\
\hline $\begin{array}{l}\text { No of } \\
\text { studies } \\
\text { (ref) }\end{array}$ & Design & Limitations & Consistency & $\begin{array}{c}\text { Generalizability } \\
\text { to population of } \\
\text { interest }\end{array}$ & $\begin{array}{l}\text { Generalizability } \\
\text { to intervention } \\
\text { of interest }\end{array}$ & Intervention & Control & $\begin{array}{c}\text { Relative Risk } \\
\text { (95\% Cl) }\end{array}$ \\
\hline \multicolumn{9}{|c|}{ Any anti-retroviral use for HIV and stillbirth: MODERATEoutcome specific quality } \\
\hline 6 & RCTs & none & $\begin{array}{l}\text { Some heterogeneity from } \\
\text { meta-analysis; } 4 \text { out of } 8 \text { data } \\
\text { sets showing benefit }\end{array}$ & Yes & Yes & 22 & 22 & $\begin{array}{c}R R(\text { fixed })=0.93 \\
\quad(0.45-1.92)\end{array}$ \\
\hline
\end{tabular}


Table 4 Quality assessment of trials of interventions for infections (bacterial vaginosis) in pregnancy

\begin{tabular}{|c|c|c|c|c|c|c|c|c|}
\hline \multicolumn{6}{|c|}{ Quality Assessment } & \multicolumn{3}{|c|}{ Summary of Findings } \\
\hline & & & & \multicolumn{2}{|c|}{ Directness } & \multicolumn{2}{|c|}{ No of events } & \multirow[b]{2}{*}{$\begin{array}{l}\text { Odd Ratios } \\
(95 \% \mathrm{Cl})\end{array}$} \\
\hline $\begin{array}{l}\text { No of } \\
\text { studies } \\
\text { (ref) }\end{array}$ & Design & Limitations & Consistency & $\begin{array}{c}\text { Generalizability } \\
\text { to population } \\
\text { of interest } \\
\end{array}$ & $\begin{array}{c}\text { Generalizability } \\
\text { to intervention } \\
\text { of interest } \\
\end{array}$ & Intervention & Control & \\
\hline \multicolumn{9}{|c|}{ Antibiotics for bacterial vaginosis and perinatal death: MODERATEoutcome specific quality } \\
\hline 4 & RCTs & $\begin{array}{c}\text { Low recruitment response } \\
\text { in one study, also } \\
\text { allocation concealment } \\
\text { unclear }\end{array}$ & $\begin{array}{l}\text { Some heterogeneity } \\
\text { in meta-analysis; } 3 / 4 \\
\text { studies show benefit }\end{array}$ & Yes & Yes & 23 & 26 & $\begin{array}{c}O R=0.88 \\
(0.50-1.55)\end{array}$ \\
\hline
\end{tabular}

The review employs a comprehensive search strategy thus increasing the chance of retrieving all relevant studies. Mainly randomized controlled and quasi randomized trials have been considered that provide a high quality level of evidence. It is however important to note that data from interventional studies were scarce. A high quality research agenda addressing the contribution of infections to stillbirth, especially in developing countries, is needed to reduce stillbirths worldwide. At present, large gaps exist in the growing list of stillbirth risk factors, especially those that are infection related [72]. The clearest evidence of impact on stillbirth prevention is adequate prevention and treatment of infections such as syphilis and possibly malaria. Other potential causes of stillbirth including HIV, bacterial vaginosis, ascending infections and TORCH infections need to be investigated further to help establish the role of prevention/treatment and its subsequent impact on stillbirth reduction [72]. Efficacious interventions exist for certain maternal infections and conditions for which the evidence of plausible benefit is not very clear. Therefore, efforts need to be geared to conduct high quality trials for us to ascertain the full extent of the relation between interventions and their potential to reduce stillbirths.

\section{Conclusions}

The clearest evidence of impact in stillbirth reduction is adequate prevention and treatment of maternal infections such as syphilis and possibly malaria. At present, large gaps exist in the growing list of stillbirth risk factors, especially those that are infection related.

\section{Key Messages}

A reduction of $80 \%$ is observed in the incidence of stillbirths in pregnant women with syphilis receiving penicillin.

Malaria prevention intervention in pregnancy through IPTp and ITNs providemay reduce stillbirths by $22 \%$ during the first or second pregnancy in areas of stable $P$. falciparum malaria transmission.

More studies need to be conducted to determine the effectiveness of interventions for diseases such as HIV, ascending bacterial infections and TORCH infections for reducing stillbirths.

\section{Additional material}

Additional File 1: A word document containing a review of literature for specific infections related to stillbirths.

Additional File 2: A word document containing the basic search strategies and terms used for specific infections.

Additional File 3: An excel file that contains the data extraction sheet of studies included in the review.

Additional File 4: A word file that described the characteristics of studies included in the main meta-analysis.

\section{Acknowledgements}

This work was supported in part by a grant to the US Fund for UNICEF from the Bill \& Melinda Gates Foundation (grant 43386) to "Promote evidencebased decision making in designing maternal, neonatal and child health interventions in low- and middle-income countries".

This article has been published as part of BMC Public Health Volume 11 Supplement 3, 2011: Technical inputs, enhancements and applications of the Lives Saved Tool (LiST). The full contents of the supplement are available online at http://www.biomedcentral.com/1471-2458/11?issue=\$3.

\section{Author details}

${ }^{1}$ Division of Women and Child Health, The Aga Khan University, Stadium Road, P.O. Box 3500, Karachi-74800, Pakistan. ${ }^{2}$ Drexel University College of Medicine, Philadelphia, USA. ${ }^{3}$ Department of International Health and Development, Tulane University School of Public Health and Tropical Medicine, New Orleans LA, USA.

\section{Authors' contributions}

Professor Zulfiqar A Bhutta developed the review parameters and secured support. Drs Sidra Ishaque, Yawar Yakoob and Aamer Imdad, undertook the literature search, data extraction and analysis with advice and input from Professor Robert Goldenberg, Dr Thomas Eisele and Professor Bhutta. Professor Zulfiqar A. Bhutta gave advice on all the aspects of the project and was the overall supervisor.

\section{Competing interests}

The authors declare no conflict of interests.

Published: 13 April 2011

\section{References}

1. Lawn JE, Yakoob MY, Haws RA, Soomro T, Darmstadt GL, Bhutta ZA: 3.2 million stillbirths: epidemiology and overview of the evidence review. BMC Pregnancy Childbirth 2009, 9(Suppl 1):S2.

2. Goldenberg RL, McClure EM, Saleem S, Reddy UM: Infection-related stillbirths. Lancet 375(9724):1482-1490. 
3. Goldenberg RL, Thompson C: The infectious origins of stillbirth. Am J Obstet Gynecol 2003, 189(3):861-873.

4. Herschel M, Hsieh HL, Mittendorf R, Khoshnood B, Covert RF, Lee KS: Fetal death in a population of black women. Am J Prev Med 1995, 11(3):185-189.

5. Goldenberg RL, Hauth JC, Andrews WW: Intrauterine infection and preterm delivery. N Engl J Med 2000, 342(20):1500-1507.

6. Goldenberg RL, Culhane JF, Johnson DC: Maternal infection and adverse fetal and neonatal outcomes. Clin Perinatol 2005, 32(3):523-559.

7. Desai M, ter Kuile FO, Nosten F, McGready R, Asamoa K, Brabin B, Newman RD: Epidemiology and burden of malaria in pregnancy. Lancet Infect Dis 2007, 7(2):93-104.

8. Stegmann BJ, Carey JC: TORCH Infections. Toxoplasmosis, Other (syphilis, varicella-zoster, parvovirus B19), Rubella, Cytomegalovirus (CMV), and Herpes infections. Curr Womens Health Rep 2002, 2(4):253-258.

9. Maruyama Y, Sameshima H, Kamitomo M, Ibara S, Kaneko M, Ikenoue T, Minematsu T, Eizuru Y: Fetal manifestations and poor outcomes of congenital cytomegalovirus infections: possible candidates for intrauterine antiviral treatments. J Obstet Gynaecol Res 2007, 33(5):619-623.

10. Xiong X, Buekens P, Vastardis S, Yu SM: Periodontal disease and pregnancy outcomes: state-of-the-science. Obstet Gynecol Surv 2007, 62(9):605-615.

11. Gursoy M, Pajukanta R, Sorsa T, Kononen E: Clinical changes in periodontium during pregnancy and post-partum. J Clin Periodontol 2008, 35(7):576-583.

12. Cruz SS, Costa Mda C, Gomes-Filho IS, Rezende EJ, Barreto ML, Dos Santos CA, Vianna MI, Passos JS, Cerqueira EM: Contribution of periodontal disease in pregnant women as a risk factor for low birth weight. Community Dent Oral Epidemiol 2009, 37(6):527-533.

13. Michalowicz BS, Hodges JS, DiAngelis AJ, Lupo VR, Novak MJ, Ferguson JE, Buchanan W, Bofill J, Papapanou PN, Mitchell DA, et al: Treatment of periodontal disease and the risk of preterm birth. N Engl J Med 2006, 355(18):1885-1894.

14. Polyzos NP, Polyzos IP, Mauri D, Tzioras S, Tsappi M, Cortinovis I, Casazza G: Effect of periodontal disease treatment during pregnancy on preterm birth incidence: a metaanalysis of randomized trials. Am J Obstet Gynecol 2009, 200(3):225-232

15. Xiong X, Buekens P, Fraser WD, Beck J, Offenbacher S: Periodontal disease and adverse pregnancy outcomes: a systematic review. BJOG 2006, 113(2):135-143.

16. Offenbacher S, Beck JD, Jared HL, Mauriello SM, Mendoza LC, Couper DJ, Stewart DD, Murtha AP, Cochran DL, Dudley DJ, et al: Effects of periodontal therapy on rate of preterm delivery: a randomized controlled trial. Obstet Gynecol 2009, 114(3):551-559.

17. Haider BA, Humayun Q, Bhutta ZA: Effect of administration of antihelminthics for soil transmitted helminths during pregnancy. Cochrane Database Syst Rev 2009, , 2: CD005547.

18. World Health Organization: WHO Report of the informal consultation on hookworm infection and anaemia in girls and women. (WHO/CTD/SIP/96.1) Geneva: World Health Organization; 1995.

19. Bundy DA, Chan MS, Savioli L: Hookworm infection in pregnancy. Trans $R$ Soc Trop Med Hyg 1995, 89(5):521-522.

20. Walker N, Fischer-Walker C, Bryce J, Bahl R, Cousens S: Standards for CHERG reviews of intervention effects on child survival. Int I Epidemiol 2010, 39(Suppl 1):i21-31.

21. Atkins $D$, Best $D$, Briss PA, Eccles M, Falck-Ytter Y, Flottorp $S$, Guyatt $G H$, Harbour RT, Haugh MC, Henry D, et al: Grading quality of evidence and strength of recommendations. BMJ 2004, 328(7454):1490.

22. RevMan : The Cochrane Colloboration. Review Manager (RevMan) 5 for Windows. Oxford, England; 2003.

23. Blencowe H, Cousens S, Kamb H, Lawn JE: Detection and treatment of syphillis in pregnancy to prevent syphillis related stillbirths and neonatal mortality. BMC Public Health 2011.

24. Menendez C, Bardaji A, Sigauque B, Romagosa C, Sanz S, Serra-Casas E, Macete E, Berenguera A, David C, Dobano C, et al: A randomized placebocontrolled trial of intermittent preventive treatment in pregnant women in the context of insecticide treated nets delivered through the antenatal clinic. PLoS One 2008, 3(4):e1934.

25. Parise ME, Ayisi JG, Nahlen BL, Schultz LJ, Roberts JM, Misore A, Muga R, Oloo AJ, Steketee RW: Efficacy of sulfadoxine-pyrimethamine for prevention of placental malaria in an area of Kenya with a high prevalence of malaria and human immunodeficiency virus infection. Am J Trop Med Hyg 1998, 59(5):813-822.

26. Shulman CE, Dorman EK, Cutts F, Kawuondo K, Bulmer JN, Peshu N, Marsh K: Intermittent sulphadoxine-pyrimethamine to prevent severe anaemia secondary to malaria in pregnancy: a randomised placebocontrolled trial. Lancet 1999, 353(9153):632-636.

27. Challis K, Osman NB, Cotiro M, Nordahl G, Dgedge M, Bergstrom S: Impact of a double dose of sulphadoxine-pyrimethamine to reduce prevalence of pregnancy malaria in southern Mozambique. Trop Med Int Health 2004, 9(10):1066-1073.

28. Dabis F, Elenga N, Meda N, Leroy V, Viho I, Manigart O, DequaeMerchadou L, Msellati P, Sombie I: 18-Month mortality and perinatal exposure to zidovudine in West Africa. AIDS 2001, 15(6):771-779.

29. Limpongsanurak $S$, Thaithumyanon $P$, Chaithongwongwatthana $S$, Thisyakorn U, Ruxrungtham K, Kongsin P, Tarounotai U, Chantheptaewan N, Triratwerapong T, Ubolyam $S$, et al: Short course zidovudine maternal treatment in HIV-1 vertical transmission: randomized controlled multicenter trial. J Med Assoc Thai 2001, 84(Suppl 1):S338-345.

30. Shaffer N, Chuachoowong R, Mock PA, Bhadrakom C, Siriwasin W, Young NL, Chotpitayasunondh T, Chearskul S, Roongpisuthipong A, Chinayon $P$, et al: Short-course zidovudine for perinatal HIV-1 transmission in Bangkok, Thailand: a randomised controlled trial. Bangkok Collaborative Perinatal HIV Transmission Study Group. Lancet 1999, 353(9155):773-780

31. Wiktor SZ, Ekpini E, Karon JM, Nkengasong J, Maurice C, Severin ST, Roels TH, Kouassi MK, Lackritz EM, Coulibaly IM, et al: Short-course oral zidovudine for prevention of mother-to-child transmission of HIV-1 in Abidjan, Cote d'Ivoire: a randomised trial. Lancet 1999, 353(9155):781-785.

32. Efficacy of three short-course regimens of zidovudine and lamivudine in preventing early and late transmission of HIV-1 from mother to child in Tanzania, South Africa, and Uganda (Petra study): a randomised, doubleblind, placebo-controlled trial. Lancet 2002, 359(9313):1178-1186.

33. Connor EM, Sperling RS, Gelber R, Kiselev P, Scott G, O'Sullivan MJ, VanDyke R, Bey M, Shearer W, Jacobson RL, et al: Reduction of maternalinfant transmission of human immunodeficiency virus type 1 with zidovudine treatment. Pediatric AIDS Clinical Trials Group Protocol 076 Study Group. N Engl J Med 1994, 331(18):1173-1180.

34. McDonald HM, O'Loughlin JA, Vigneswaran R, Jolley PT, Harvey JA, Bof A, McDonald PJ: Impact of metronidazole therapy on preterm birth in women with bacterial vaginosis flora (Gardnerella vaginalis): a randomised, placebo controlled trial. Br J Obstet Gynaecol 1997, 104(12):1391-1397.

35. Carey JC, Klebanoff MA, Hauth JC, Hillier SL, Thom EA, Ernest JM, Heine RP, Nugent RP, Fischer ML, Leveno KJ, et al: Metronidazole to prevent preterm delivery in pregnant women with asymptomatic bacterial vaginosis. National Institute of Child Health and Human Development Network of Maternal-Fetal Medicine Units. N Engl J Med 2000, 342(8):534-540.

36. Odendaal HJ, Popov I, Schoeman J, Smith M, Grove D: Preterm labour-is bacterial vaginosis involved? S Afr Med J 2002, 92(3):231-234

37. Lamont RF, Duncan SL, Mandal D, Bassett P: Intravaginal clindamycin to reduce preterm birth in women with abnormal genital tract flora. Obstet Gynecol 2003, 101(3):516-522

38. Kenyon $\mathrm{S}$, Boulvain $\mathrm{M}$, Neilson J: Antibiotics for preterm rupture of membranes. Cochrane Database Syst Rev 2003, 2:CD001058.

39. Flenady V, King J: Antibiotics for prelabour rupture of membranes at or near term. Cochrane Database Syst Rev 2002, 3:CD001807.

40. Drazancic A, Balasa A, Zadjelovic J, Kralj-Pejakovic L: The effect of treatment of bacteriuria on pregnancy outcome. Jugos/ Ginekol Perinatol 1989, 29(1-2):15-18.

41. Sheiner E, Mazor-Drey E, Levy A: Asymptomatic bacteriuria during pregnancy. J Matern Fetal Neonatal Med 2009, 22(5):423-427.

42. Farrell S, Ide M, Wilson RF: The relationship between maternal periodontitis, adverse pregnancy outcome and miscarriage in never smokers. J Clin Periodontol 2006, 33(2):115-120.

43. Mobeen N, Jehan I, Banday N, Moore J, McClure EM, Pasha O, Wright LL, Goldenberg RL: Periodontal disease and adverse birth outcomes: a study from Pakistan. Am J Obstet Gynecol 2008, 198(5):514 e511-518.

44. Moore S, Ide M, Coward PY, Randhawa M, Borkowska E, Baylis R, Wilson RF: A prospective study to investigate the relationship between periodontal 
disease and adverse pregnancy outcome. Br Dent J 2004, 197(5):251-258, discussion 247.

45. Newnham JP, Newnham IA, Ball CM, Wright M, Pennell CE, Swain J, Doherty DA: Treatment of periodontal disease during pregnancy: a randomized controlled trial. Obstet Gynecol 2009, 114(6):1239-1248.

46. Ndibazza J, Muhangi L, Akishule D, Kiggundu M, Ameke C, Oweka J, Kizindo R, Duong T, Kleinschmidt I, Muwanga M, et al: Effects of deworming during pregnancy on maternal and perinatal outcomes in Entebbe, Uganda: a randomized controlled trial. Clin Infect Dis 50(4):531-540.

47. Ndyomugyenyi R, Kabatereine N, Olsen A, Magnussen P: Efficacy of ivermectin and albendazole alone and in combination for treatment of soil-transmitted helminths in pregnancy and adverse events: a randomized open label controlled intervention trial in Masindi district, western Uganda. Am J Trop Med Hyg 2008, 79(6):856-863.

48. Elliott AM, Namujju PB, Mawa PA, Quigley MA, Nampijja M, Nkurunziza PM, Belisle JT, Muwanga M, Whitworth JA: A randomised controlled trial of the effects of albendazole in pregnancy on maternal responses to mycobacterial antigens and infant responses to Bacille Calmette-Guerin (BCG) immunisation [ISRCTN32849447]. BMC Infect Dis 2005, 5:115.

49. Larocque R, Casapia M, Gotuzzo E, MacLean JD, Soto JC, Rahme E, Gyorkos TW: A double-blind randomized controlled trial of antenatal mebendazole to reduce low birthweight in a hookworm-endemic area of Peru. Trop Med Int Health 2006, 11(10):1485-1495.

50. Nimri LF, Elnasser Z, Batchoun R: Polymicrobial infections in children with diarrhoea in a rural area of Jordan. FEMS Immunol Med Microbiol 2004 42(2):255-259.

51. Dayan GH, Zimmerman L, Shteinke L, Kasymbekova K, Uzicanin A, Strebel P, Reef S: Investigation of a rubella outbreak in Kyrgyzstan in 2001: implications for an integrated approach to measles elimination and prevention of congenital rubella syndrome. J Infect Dis 2003, 187(Suppl 1):S235-240.

52. Howard J, Hall B, Brennan LE, Arbuckle S, Craig ME, Graf N, Rawlinson W: Utility of newborn screening cards for detecting CMV infection in cases of stillbirth. J Clin Virol 2009, 44(3):215-218.

53. Syridou G, Spanakis N, Konstantinidou A, Piperaki ET, Kafetzis D, Patsouris E, Antsaklis A, Tsakris A: Detection of cytomegalovirus, parvovirus B19 and herpes simplex viruses in cases of intrauterine fetal death: association with pathological findings. J Med Virol 2008, 80(10):1776-1782.

54. Benirschke K, Robb JA: Infectious causes of fetal death. Clin Obstet Gynecol 1987, 30(2):284-294.

55. Watson-Jones D, Gumodoka B, Weiss H, Changalucha J, Todd J, Mugeye K, Buve A, Kanga Z, Ndeki L, Rusizoka M, et al: Syphilis in pregnancy in Tanzania. II. The effectiveness of antenatal syphilis screening and singledose benzathine penicillin treatment for the prevention of adverse pregnancy outcomes. J Infect Dis 2002, 186(7):948-957.

56. Folgosa E, Gonzalez C, Osman NB, Hagerstrand I, Bergstrom S, Ljungh A: A case control study of chorioamniotic infection and histological chorioamnionitis in stillbirth. APMIS 1997, 105(4):329-336.

57. Sethi S, Sharma K, Dhaliwal LK, Banga SS, Sharma M: Declining trends in syphilis prevalence among antenatal women in northern India: a 10-year analysis from a tertiary healthcare centre. Sex Transm Infect 2007, 83(7):592.

58. Gamble C, Ekwaru JP, ter Kuile FO: Insecticide-treated nets for preventing malaria in pregnancy. Cochrane Database Syst Rev 2006, 2:CD003755.

59. Garner P, Gulmezoglu AM: Drugs for preventing malaria in pregnant women. Cochrane Database Syst Rev 2006, 4:CD000169.

60. ter Kuile FO, van Eijk AM, Filler SJ: Effect of sulfadoxine-pyrimethamine resistance on the efficacy of intermittent preventive therapy for malaria control during pregnancy: a systematic review. JAMA 2007, 297(23):2603-2616

61. Eisele TP, Larsen D, Steketee RW: Protective efficacy of interventions for preventing malaria mortality in children in Plasmodium falciparum endemic areas. Int J Epidemiol 2010, 39(Suppl 1):i88-101.

62. van Geertruyden JP, Thomas F, Erhart A, D'Alessandro U: The contribution of malaria in pregnancy to perinatal mortality. Am J Trop Med Hyg 2004, 71(2 Suppl):35-40

63. Moodley J, Wennberg JL: HIV in pregnancy. Curr Opin Obstet Gynecol 2005, 17(2):117-121

64. Brocklehurst $P$, French $R$ : The association between maternal HIV infection and perinatal outcome: a systematic review of the literature and metaanalysis. Br J Obstet Gynaecol 1998, 105(8):836-848.
65. Chi BH, Wang L, Read JS, Taha TE, Sinkala M, Brown ER, Valentine M, Martinson F, Goldenberg RL: Predictors of stillbirth in sub-saharan Africa. Obstet Gynecol 2007, 110(5):989-997.

66. Volmink J, Siegfried NL, van der LMerwe, Brocklehurst P: Antiretrovirals for reducing the risk of mother-to-child transmission of HIV infection. Cochrane Database Syst Rev 2007, 1:CD003510.

67. Suksomboon N, Poolsup N, Ket-Aim S: Systematic review of the efficacy of antiretroviral therapies for reducing the risk of mother-to-child transmission of HIV infection. J Clin Pharm Ther 2007, 32(3):293-311.

68. McDonald HM, Brocklehurst $P$, Gordon A: Antibiotics for treating bacterial vaginosis in pregnancy. Cochrane Database Syst Rev 2007, 1:CD000262.

69. Menezes EV, Yakoob MY, Soomro T, Haws RA, Darmstadt GL, Bhutta ZA: Reducing stillbirths: prevention and management of medical disorders and infections during pregnancy. BMC Pregnancy Childbirth 2009, 9(Suppl 1):S4.

70. Di Mario S, Say L, Lincetto O: Risk factors for stillbirth in developing countries: a systematic review of the literature. Sex Transm Dis 2007, 34(7 Suppl):S11-21.

71. McClure EM, Nalubamba-Phiri M, Goldenberg RL: Stillbirth in developing countries. Int J Gynaecol Obstet 2006, 94(2):82-90.

72. Goldenberg RL, McClure EM, Saleem S, Reddy UM: Infection-related stillbirths. Lancet 2010, 375(9724):1482-1490.

73. Schmid GP, Stoner BP, Hawkes S, Broutet N: The need and plan for global elimination of congenital syphilis. Sex Transm Dis 2007, 34(7 Suppl):S5-10.

74. Walker GJ, Walker DG: Congenital syphilis: a continuing but neglected problem. Semin Fetal Neonatal Med 2007, 12(3):198-206.

75. Myer L, Wilkinson D, Lombard C, Zuma K, Rotchford K, Karim SS: Impact of on-site testing for maternal syphilis on treatment delays, treatment rates, and perinatal mortality in rural South Africa: a randomised controlled trial. Sex Transm Infect 2003, 79(3):208-213.

76. Rydzak CE, Goldie SJ: Cost-effectiveness of rapid point-of-care prenatal syphilis screening in sub-Saharan Africa. Sex Transm Dis 2008 35(9):775-784.

77. Schwarz NG, Adegnika AA, Breitling LP, Gabor J, Agnandji ST, Newman RD, Lell B, Issifou S, Yazdanbakhsh M, Luty AJ, et al: Placental malaria increases malaria risk in the first 30 months of life. Clin Infect Dis 2008, 47(8):1017-1025

78. Dorman EK, Shulman CE, Kingdom J, Bulmer JN, Mwendwa J, Peshu N, Marsh K: Impaired uteroplacental blood flow in pregnancies complicated by falciparum malaria. Ultrasound Obstet Gynecol 2002, 19(2):165-170.

79. Newman RD, Hailemariam A, Jimma D, Degifie A, Kebede D, Rietveld AE, Nahlen BL, Barnwell JW, Steketee RW, Parise ME: Burden of malaria during pregnancy in areas of stable and unstable transmission in Ethiopia during a nonepidemic year. J Infect Dis 2003, 187(11):1765-1772.

80. Oladapo OT, Adekanle DA, Durojaiye BO: Maternal risk factors associated with fetal death during antenatal care in low-resource tertiary hospitals. Aust N Z J Obstet Gynaecol 2007, 47(5):383-388.

81. UNAIDS/WHO: AIDS epidemic update. Geneva: Joint United Nations Programme on HIV/AIDS (UNAIDS); 2005.

82. Kupka R, Kassaye T, Saathoff E, Hertzmark E, Msamanga GI, Fawzi WW: Predictors of stillbirth among HIV-infected Tanzanian women. Acta Obstet Gynecol Scand 2009, 88(5):584-592.

83. Hay PE, Morgan DJ, Ison CA, Bhide SA, Romney M, McKenzie P, Pearson J Lamont RF, Taylor-Robinson D: A longitudinal study of bacterial vaginosis during pregnancy. Br J Obstet Gynaecol 1994, 101(12):1048-1053.

84. Hillier SL, Nugent RP, Eschenbach DA, Krohn MA, Gibbs RS, Martin DH, Cotch MF, Edelman R, Pastorek JG 2nd, Rao AV, et al: Association between bacterial vaginosis and preterm delivery of a low-birth-weight infant. The Vaginal Infections and Prematurity Study Group. N Engl J Med 1995 333(26):1737-1742

85. Kurki T, Hallman M, Zilliacus R, Teramo K, Ylikorkala O: Premature rupture of the membranes: effect of penicillin prophylaxis and long-term outcome of the children. Am J Perinatol 1992, 9(1):11-16.

86. McGregor JA, French Jl, Seo K: Antimicrobial therapy in preterm premature rupture of membranes: results of a prospective, double-blind, placebo-controlled trial of erythromycin. Am J Obstet Gynecol 1991, 165(3):632-640.

87. Whalley P: Bacteriuria of pregnancy. Am J Obstet Gynecol 1967, 97(5):723-738. 
88. Madan E, Meyer MP, Amortequi A: Chorioamnionitis: a study of organisms isolated in perinatal autopsies. Ann Clin Lab Sci 1988, 18(1):39-45.

89. Jones JL, Lopez A, Wilson M, Schulkin J, Gibbs R: Congenital toxoplasmosis: a review. Obstet Gynecol Surv 2001, 56(5):296-305

90. Forrest JM, Turnbull FM, Sholler GF, Hawker RE, Martin FJ, Doran TT, Burgess MA: Gregg's congenital rubella patients 60 years later. Med J Aust 2002, 177(11-12):664-667.

91. McClure EM, Goldenberg RL: Infection and stillbirth. Semin Fetal Neonatal Med 2009, 14(4):182-189.

92. Griffiths PD: Advances in the prevention and treatment of cytomegalovirus infection in hospital patients. J Hosp Infect 1991, 18(Suppl A):330-334.

93. Khare $M$, Sharland M, Manyonda I, Rice P, Bland JM, Griffiths P: Use of serial maternal urine cytomegalovirus PCR to detect primary CMV infection in seronegative pregnant women. J Virol Methods 2004, 119(1):31-35.

94. Eskild A, Jeansson S, Stray-Pedersen B, Jenum PA: Herpes simplex virus type-2 infection in pregnancy: no risk of fetal death: results from a nested case-control study within 35,940 women. BJOG 2002, 109(9):1030-1035.

95. Gibbs RS: The origins of stillbirth: infectious diseases. Semin Perinatol 2002, 26(1):75-78.

96. Copper RL, Goldenberg RL, DuBard MB, Davis RO: Risk factors for fetal death in white, black, and Hispanic women. Collaborative Group on Preterm Birth Prevention. Obstet Gynecol 1994, 84(4):490-495.

97. Fretts RC: Etiology and prevention of stillbirth. Am J Obstet Gynecol 2005 193(6):1923-1935.

doi:10.1186/1471-2458-11-S3-S3

Cite this article as: Ishaque et al:: Effectiveness of interventions to screen and manage infections during pregnancy on reducing stillbirths: a review. BMC Public Health 2011 11(Suppl 3):S3.

\section{Submit your next manuscript to BioMed Central and take full advantage of:}

- Convenient online submission

- Thorough peer review

- No space constraints or color figure charges

- Immediate publication on acceptance

- Inclusion in PubMed, CAS, Scopus and Google Scholar

- Research which is freely available for redistribution

Submit your manuscript at www.biomedcentral.com/submit
Biomed Central 